This study examines the impact of state welfare reform policies on the paternal involvement of low-income single fathers. Life history interviews were conducted with 40 African American fathers participating in a community-based parenting program in Chicago. Men's rightful claims to fatherhood were constructed through voluntary involvement with their children and enforced paternity establishment. Welfare policies gave precedence to child support and providing and dismissed fathers' in-kind caregiving. Policy requirements reflected limited understanding of related caregiving and providing aspects of fatherhood as they vary across race and class. Family welfare policies that prioritize finances over care may curtail paternal involvement altogether; they may also adversely affect the well-being of poor children, who could benefit from the potential commitment of their fathers.

\title{
Low-Income Single Fathers in an African American Community and the Requirements of Welfare Reform
}

\author{
KEVIN ROY \\ Northwestern University
}

To me, that's the easy way out: give [the kids] some money and then run off. The money doesn't comfort them at night. They can't say, "Hey, Dollar Bill, I had a nightmare last night" and expect the Dollar Bill to rock them and hold them. Money is there because it is a necessity. But if you give a child love and attention, money is the last thing they are going to look for. (Isaiah, age 40)

The "new paternalism" encouraged by federal welfare reform (Mead, 1997), known as the Personal Responsibility and Work Opportunity Reconciliation Act of August 1996 (PRWORA), extends behavioral requirements not only to single mothers and children but to noncustodial fathers as well. Under a variety of state-tailored plans for Temporary Assistance to Needy Families (TANF), mothers lose public aid benefits if they do not identify fathers, who must voluntarily or through DNA testing establish legal paternity for their children. Fathers pay monthly amounts of financial support to the children, although typically mothers and children only receive "pass-through" amounts, which vary by state,

Author's Note: This research was supported by a doctoral dissertation grant from Northwestern University. 
while the remainder is delivered to the state welfare system to defray public aid payments. Low-income fathers evolve into "Dollar Bills," or limited potential financial resources, for their children. Paternal involvement differs, however, when defined by single fathers and mothers themselves.

Custody reflects the physical possession of children in a residential household, often defined for men through the legality of marriage. Lowincome single fathers are disqualified from access to certain public services because legal noncustodial status suggests that their children do not live with them on a consistent basis. Custody itself, however, is a dynamic state in the lives of low-income families. Single fathers keep their children over weekends and holidays, share child care, or live with their children on a month-to-month basis. Their support may be vital to the lives of their children, although noncustodial status does not convey this vitality.

In addition to custody through marriage, social policies grant men rightful claims to fatherhood through their employment status. Lowincome single fathers differ from men who find steady employment with family-supporting wages, as well as other noncustodial "deadbeat" fathers who owe child support and choose not to pay. Low-income single fathers are assumed to be avoiding their responsibilities of financial support, when in fact they may actually be "dead broke," unable to pay in spite of efforts to be good fathers.

In this study, I ask: How do welfare reform policies shape the paternal involvement of low-income single African American fathers? Discrepancies between policies and lives emerge in three aspects of paternal involvement: rightful claims to fatherhood, financial support, and caregiving and access to children. I find that policies designed only to promote the financial involvement of low-income single fathers can discourage their paternal involvement altogether. The behavioral requirements of these policies are rooted in a limited understanding of caregiving and providing activities for all fathers across race and class. These requirements inhibit family policies from being truly effective at enhancing children's well-being.

\section{THEORY AND RELEVANT LITERATURE}

\section{FATHERS AS CAREGIVERS AND PROVIDERS}

Over the past two decades, social scientists have vigorously developed fatherhood as a construct distinct from motherhood or parenting. 
Lamb, Pleck, Charnov, and Levine's (1987) conception of three domains of paternal involvement-interaction, access, and responsibility - provided a foundation for other psychological research to diversify qualitative definitions of involvement (Dollahite, Hawkins, \& Brotherson, 1997; Palkovitz, 1997). Sociological research on fathers, most prominently the work of Gerson (1993), Daly (1995), Coltrane (1996), and LaRossa (1997), expanded on previously held notions of fatherhood through a focus on men's increasing involvement as caregivers. The nurturant aspect of fatherhood was often neglected due to the normative expectations of the good provider/father (Bernard, 1981).

Recent years have seen increases in the number of fathers who give care as well as the number of single fathers who are unable to contribute financially to their families (Furstenberg, 1988). Some researchers suggest that the nonresidential family structure incurs further disengagement from financial support (Doherty, 1997). Inability to provide runs contrary to normative expectations of responsible fatherhood (Lupton \& Barclay, 1997) and has led to a characterization of single fathers, often poor and minority men, as absent parents. Despite survey data showing that poor and minority fathers may be involved as caregivers (Stier \& Tienda, 1993), perhaps even to a greater extent than nonpoor nurturant fathers (Cohen, 1998), their involvement is increasingly dismissed due to their marginalization from employment.

A shift from studying normative paternal involvement to examining the rich variety of fatherhood experiences may provide insight into the dynamic relationship between caregiving and providing. Previous research recognizes that racial, ethnic, and class differences do exist between fathers (Palkovitz, 1997), but still little is known about how strongly these differences affect the social construction of fatherhood roles in the United States (Griswold, 1993). Different environments affect human development (Bronfenbrenner, 1979), and families exposed to violence on a daily basis, for example, may find inconsistent conditions for caregiving and providing (Garbarino, Dubrow, Kostelny, \& Pardo, 1992). An integrated theory of fatherhood identity construction would address varying environments, as well as structures of the institutional life course, such as family, work, and social policy (Marsiglio, 1995).

\section{AFRICAN AMERICAN FATHERS ON THE MARGINS OF FAMILY AND WORK}

Although smaller as a total group, greater percentages of young African American men are low-income single fathers, compared to 
Latino and European American fathers (Lerman, 1993). New degrees of economic marginalization brought on by the postindustrial economy threaten the regular involvement of African American men with their children (Bowman, 1988; Duster, 1995; W. Johnson, in press; McLoyd, 1989; Taylor, Leashore, \& Toliver, 1988; Wacquant, 1996; Wilson, 1996). Social isolation from family as well as unemployment and underemployment often result (E. Johnson \& Doolittle, 1996). With the possibility that kin resources are declining (Roschelle, 1997), mothers may look to low-income single fathers to make any effort that they can to be involved with their children (Ray \& Hans, 1997). Many of these fathers in African American families express simply "being there" as an involved father as their greatest priority (Allen \& Connor, 1997; Allen \& Doherty, 1996).

Studies of the family life of low-income single African American fathers demonstrate that men solidify their biological ties as fathers through efforts to support their children financially, emotionally, and physically (Anderson, 1990; Liebow, 1967; Rainwater, 1970). Furstenberg (1988, 1992, 1995) found that "shadow fathers" earn their parenting roles by "doing for" their children. Most of these fathers, however, cannot sustain a high level of involvement over time. Using a method of examining the kin-scripted life course (Stack \& Burton, 1993), Stack (1974) explored men's lives in the context of highly charged negotiation over sharing children among kin, as well as within the welfare system's legal requirements of fathers.

\section{SOCIAL POLICY AND RIGHTFUL CLAIMS TO FATHERHOOD}

Policy research on welfare reform and families places low-income single fathers at the center of the debate on financial support (Edin \& Lein, 1997; Garfinkel, McLanahan, \& Robins, 1992). Rightful claims to responsible fatherhood emerge almost exclusively through financial involvement with children, a corollary to welfare reform work obligations for responsible motherhood (Epstein, 1997). Showing evidence of poor job opportunities and fragile family relationships of low-income fathers has done little to change policy debate (Mincy \& Pouncy, 1997; Mincy \& Sorensen, 1998). Anderson (1990) and Furstenberg (1992) provide ethnographic evidence of how fathers continue to resist welfare policies that intervene in the informal negotiations of low-income single parents. 
Few studies have taken a broader policy perspective into account, incorporating individual agency and structural constraints (Brewer, 1994; Jarrett, 1994; Sullivan, 1989). Sullivan (1993) discusses paternity establishment with fathers from African American and Latino innercity communities. He found that, without adequate jobs, fathers relied on "folk" understandings of their roles and that they avoided the formal legal system. Waller (1996) also found that low-income single fathers and their coparents defined paternal involvement differently than the welfare state. Legal insistence on financial support dismissed families' own definitions of good fathering for single men (Waller, 1997). Recent research on dramatic changes in welfare policies since 1996 suggests that tensions between legal and family-based systems of support may have been exacerbated (Boggess \& Roulet, 1998).

\section{SAMPLE AND METHOD}

In previous research, social scientists have had difficulty gaining access to low-income single fathers in urban communities. I worked for 3 years as a researcher in a fatherhood program based in a Chicago community college. I spent 20 hours each week conducting interviews and surveys, as well as doing case management. I interacted with the same participants over many months as they clarified questions that emerged from initial interview text. Fathers were quite interested in sharing their experiences when they could carefully explain meanings. Few people had ever given their lives any credence, except as stereotypes of poor African American noncustodial fathers.

The program received public and private funding and provided employment training and placement, parenting classes, educational referrals, and coparenting counseling to noncustodial fathers whose children received public aid. The program staff advocated for fathers, helping them to resolve court cases, establish paternity, and untangle complicated new welfare reform requirements. Over 400 fathers, $99 \%$ of whom were African American, voluntarily enrolled over 2 years. Participants were typically unemployed and looking for work, with an average of 2.3 children. Friends, family, or the child support enforcement agency referred fathers to the program, although they were not mandated to enroll. Smaller numbers came from substance abuse treatment programs, correctional centers, and the Salvation Army. 
Illinois' "wait and see" perspective on welfare reform has translated into relatively recent and moderate policy changes, as compared to states at the forefront of rapid and punitive new legislation. Through advocacy efforts, a state agency was created in 1996 to aid noncustodial fathers; through the agency, Illinois refers men to community-based or state-run earnfare programs for employment training and placement. Fathers are required to pay off their arrearage at a minimal rate of $\$ 10$ each month if they cooperate with the child support system. "Deadbeat" fathers often lose their driving or business licenses due to excessive arrearage; however, few fathers in the parenting program have driver's licenses or own cars and businesses. Illinois is considering nonsupport criminalization policies for the first time in 1999, which would bring it in line with the majority of state plans, which allow for incarceration due to nonpayment of child support arrearage.

Forty participants were chosen for interviews. Staff referred fathers who seemed committed to involvement with their children, as reflected in consistent attendance at employment or parenting sessions. This sample, one could argue, may consist of highly involved fathers, although the demographic variation among these fathers reflected the age and education of the larger group of 400 fathers. The sample was divided into three cohorts: 35 years and older $(n=15), 24$ to 34 years old $(n=$ $15)$; and 17 to 23 years old $(n=10)$.

Half of the fathers (20 of 40) had set up family households with coresident partners at one time. Almost a third of the fathers (12 of 40) spent at least some time as live-in partners with a coparent and her children. A quarter of fathers (9 of 40) never resided or spent any significant amount of time with their families, except for occasional visits with their children. Although not regarded as custodial parents, these men lived near their children, visited them, and kept them overnight or for longer periods of time during holidays and summer vacations.

Interviews with the fathers reflected my interest in both structural and phenomenological approaches to the social construction of fatherhood (Lupton \& Barclay, 1997). During 2-hour sessions, I conducted retrospective life history interviews and recorded the timing and sequencing of transitions and life events such as departures from parental homes, exits from and entries into the labor market, and births of children on calendar grids (using techniques found in Freedman, Thornton, Camburn, Alwin, \& Young-Demarco, 1988).

Semistructured interview questions focused on father, child, and coparent interaction (based on Lamb et al., 1987), family of origin, 
residence, employment, and education. Only two specific questions addressed welfare reform policies (Have you established paternity for your children? Do you pay child support for your children?). Although not designed to address social policies, three other questions (How has your involvement with your children changed over time? What agreement/understanding have you established with their mother to be with your children? What does it mean to you to be a responsible father?) developed into discussions of visitation and custody, child support, state family services, and public aid systems. Interviews were conducted from 1997 to 1998 and reflect fathers' experiences with the most recent changes in welfare reform policies in Illinois.

Interviews were tape-recorded and transcribed and finally coded and analyzed with QSR NUDist qualitative data analysis program. Using the basic elements of grounded theory approach (Glaser \& Strauss, 1967), I coded themes that emerged from the data. I spoke with interviewed fathers about these themes, and they fine-tuned my conceptions of their involvement. Codes for three aspects of paternal involvement, which reflected discrepancies between fathers' experiences and policy requirements, resulted:

Rightful claims to fatherhood, as defined by biological proof, consistent efforts to be involved, and establishment of legal paternity

Financial support, ranging from monthly child support to in-kind resources such as food or clothing

Caregiving and access to children, including sharing of children, short-term informal custody, visitation and custody cases, and interaction with the family services/foster care system

\section{FINDINGS}

Men in this study used the phrases "taking care of my kids" and "being there for my children" to describe their involvement. A good father relied on a complex weave of responsibility, role modeling, communication, sacrifice, provision, self-knowledge, and guidance. For example, Gil, 27, took care of his daughter with monthly checks and child support, weekly visits, month-long stays during the summer, and emotional guidance. Consistent and ideal involvement integrated providing and caregiving. One activity did not have priority over the other, because although "money . . . is a necessity," it was not the most important goal as a parent. 
Fathers recognized, however, that welfare reform policies limited notions of involvement. 'The government says 'We want Dad around.' Then the government turns around and says 'Dad pays child support or we lock him up.' Dad gets lost just trying to survive. It's like society is tearing itself up" (Joe, 40).

Policies separated and prioritized caregiving and providing as distinct functions. Support was defined as providing for and maintaining children younger than the age of 18. Illinois welfare reform policies of 1996 required

a legal bond with the child through enhanced identification and paternity establishment mechanisms

financial provision for child's well-being, in the form of child support

Caregiving, which involved regular access to children, was not addressed under welfare reform guidelines. In effect, an integrated vision of taking care of one's children was dismissed by the design of welfare reform policies in favor of enforced financial support to defray public aid benefits provided by Illinois.

In the findings section, I will examine the discrepancies between requirements of welfare reform in Illinois and the lives of low-income single African American fathers. Three aspects of paternal involvement (rightful claims to fatherhood, financial support, and caregiving and access to children) shape the environment in which many fathers develop and sustain relationships with their children.

\section{RIGHTFUL CLAIMS TO FATHERHOOD}

\section{Voluntary and Consistent Involvement With Children}

Families conveyed a claim of rightful fatherhood to biological fathers who made consistent efforts to be involved. Similar to Waller's (1996) findings, a father did not offer a proper relationship with his child unless he entered voluntarily into that relationship. Even with these efforts, consistent care or contribution was difficult to come by with sporadic employment and separation from the family residence.

Partners' pregnancies marked a change in lifestyle for many fathers. Men were challenged to curtail their days as "players" and give priority to one woman and one child. Parenthood "snapped [men] out of the nonsense" of gang involvement. 
I was somewhat of a kamikaze. Whenever there was an incident where there was a conflict, I was willing to go all out. Kill or be killed. So when she let me know she was pregnant, that's about the only thing that slowed me down. I decided that you're going to have nobody to carry your name on, and there ain't no need to be going out anyway. (Ruben, 32)

Although consistent paternal involvement may have the best chance to begin at birth, it took some fathers months to commit to their children. Often, this was due to the volatility of relationships with the mothers of their children and the difficulty of creating a parenting role outside of an intimate relationship or residence. The young ages of some fathers, or the lifestyles which they led, often made them appear to be absent, when later they did commit to their children:

I denied it, I knew it was mine, but I denied it because I was living with another girl. When the baby came, I tried to sign the birth certificates, but they were gone from the hospital when I got there. The second time, I denied it again. I knew I couldn't deny it. . . . I was a dog. I was really bad. But Erica was still there. [My grandfather came to me in a dream and told me I had to marry the mother of my kids]. I've been with Erica ever since. (Kelvin, 28)

For Isaiah, 40, fatherhood meant sole responsibility for his daughter, whom he took into his home when her mother was unable to care for the child due to extended periods of substance abuse.

I just knew that she was my child. I was taking care of her, I keep her every weekend, I buy her clothes and food. I've been taking care of her since she was 1 year old without paternity being established. (Isaiah, 40)

Given the push to identify biological fathers, Isaiah could not obtain custody of his daughter without first proving paternity. Even with the mother's approval, the courts dismissed 4 years of consistent involvement when he was found not to be the biological father of his child. Although the biological father could not be identified, he lost custody of his daughter to the state foster care system.

\section{Enforced Identification and Testing}

Policy makers gave precedence to biology over consistent efforts to be involved. They did little to acknowledge that fathers had taken responsibility for their children, especially by not recognizing 
predictable environments of care for low-income families. Although families preferred voluntary efforts to take care of children, welfare reform policies enforced a father identification process. Mothers who received public aid were threatened with termination of their benefits unless the biological fathers of their children could be "smoked out."

Some men did not understand that new legislation required mothers to identify them, which caused animosity between coparents. Fathers demanded to know who put their names into the system when they received unexpected notification of court dates.

I got a court order to go to child support downtown. If the judge told me to go to this class, I'll do it, because I need a job. The kids' mother was the same way, agreeing with it all. Then I had second thoughts, because I was kind of mad, I thought that she had put them on me. She said that public aid did it. But some people try to tell her what to do and she does it. It's he said, she said. I really couldn't tell if the system made her do it. I was going to take care of my kids, even with no money, no matter what. (Cory, 27)

Many fathers self-identified themselves in the hospital at birth. Hospital staff often assumed that young men were not serious about parenting. "I tried to claim paternity [at the hospital] for both my daughters, but I didn't know the procedure to go through. I asked and the nurses just ignored me, you know what I'm saying?" (Antoine, 42).

Other fathers willingly entered court to establish paternity. They were greeted with quizzical looks, and staff had little idea how to process requests for voluntary acknowledgment of paternity. Single fathers, if mothers did not consent to the process, were required to pay out of pocket for legal services and paternity tests, whereas statepromoted paternity tests and services were free for single mothers who received public aid. Men were determined, however,

to make sure my child knew who her daddy was. . . . I didn't know anything about the courts. I felt they were very intimidating, not friendly at all. It was real hard, stressful. I mean, I was the one who wanted to prove this was my child. I wasn't denying it. They asked me how I was going to pay for court fees. I said I didn't know. (Gil, 27)

Recent legislation in Illinois has licensed hospital and community programs to establish paternity. What was accomplished only in court prior to welfare reform can now be accomplished through an administrative "consensual" process. However, this process still led to difficulty 
in establishing paternity. Even after he volunteered paternity, one father's coparent attempted to replace his name with her current boyfriend's.

She didn't come to court proceedings. She was represented by the state, and I got the letters and went down to clear it up. I had to defend myself. She put in my name ... something to do with paternity, she said. But she put the wrong name on it, and it didn't work out the way she thought it would. (Tremaine, 22)

If either parent contested paternity, fathers scientifically proved their linkages through blood or DNA testing. Men tended to distrust the emphasis on scientific "proof" necessary to be deemed a rightful father by welfare reform policies. A tremendous sense of vindication accompanied a positive test. Isaiah, after losing custody of one daughter, gained custody of another after proving his biological link: "When I got the paternity test back and it said $99.97 \%$ chance of her being my child, my chest stuck out. There was no way in the world that anyone could dispute the fact that I was the father" (Isaiah, 40).

\section{Problems With Notification}

Reducing a socially based family recognition of paternity to a bureaucratic process presented many problems with notification and follow-up, as child support, custody, visitation, and other decisions rested on this ruling. Court documents were lost in the mail, and both fathers and mothers missed court dates. "As far as paperwork goes, I don't know where he's at," Ruben admitted about his middle son, the only child for whom he did not have paternity established. "The hospital closed down a year after he was born, and there are no records. It's red-tape rhetoric." Another admitted,

Don't have it. I've been in the process of doing it, and it's just a matter of time, of her taking time out, and me too. She works a lot, I go to school, I look for work. It's just a time factor. But she's agreed, we've talked about it, and she says no problem. (Fenton, 21)

For others, children were born during prison terms or military service in Somalia, and nothing was formalized at the time of birth. In contrast, men automatically obtained paternity if they were married, through policy's grant of rightful fatherhood. 
Paternity cases rematerialized over time as well, with years of unpaid arrearages, which led state agencies to believe that fathers had run from their responsibilities. Doc discovered that he had an 8-year-old daughter for the first time when the courts served a letter to his parents, "scaring them and telling them that they were going to lock me up." Doc insisted that he would not have run away from this child if he had known about her birth. He resented the financial obligations required of him in the face of not being allowed to develop a supportive and caring relationship: "The courts had a field day with me. My whole life changed after that. Sometimes, I don't even get the proper sleep at night. That made me turn against the kid" (Doc, 35).

Decades of social policies that prohibited cohabitation with mothers receiving public aid formed the background for distrust of any paternity system. Although Illinois passed legislation to permit cohabitation among unmarried families receiving public aid in 1996, few fathers knew about the law. Some men wanted to protect their fragile family relationships, insisting "I'm not going [away from my baby and her mother], so why establish paternity?" Many others needed to maintain public aid benefits in a difficult job market and believed that paternity would lead to manipulation or even termination of benefits: "[I don't have paternity established] for Little Mike ... she wasn't working at the time and I was working at the car wash, and we didn't have any money coming in, so to keep her money coming in she didn't say anything" (Miles, 30).

\section{Support for Paternity Establishment?}

A few fathers willingly accepted the state's role as gatekeeper of paternity. They sought a guarantee of legal paternal ties to their child, in case of emergency, or in case the custodial parent tried to remove the child from their lives. Bird, a 20-year-old former gang banger, knew that "I want to establish paternity, so she can't say, 'you can't see your shorty, and I'm taking her elsewhere." Curt, 36, refused to provide money to his child's mother when he was 19 , because she would not allow him to see his child. He felt that he "shouldn't take care of someone that I can't even see, so she took me to court, and I never denied my paternity. Took the test [and was happy with the result]." External arbitration of paternity helped to decrease tension over coparenting for these fathers. 
It was rare to find fathers who felt that the paternity system supported their sincere efforts, however, and therefore most men opted to resist recent policies in Illinois. Policy makers cast suspicion on fathers' efforts to be involved. Some fathers were so consumed by the difficulties in proving a legitimate relationship to their children that they became distracted from acting like "good fathers."

People don't have enough information or education about [the laws]. Or if they do, they're still being manipulated. How can you concentrate on a child if you yourself are [doubted] . . . you spiral down. If I can't help myself, how can I help somebody else? (Lamont, 27)

\section{PROVIDING FINANCIAL SUPPORT}

\section{Disincentives to Participation in Child Support}

Fathers knew that their efforts to take care of their children financially did not measure up to success according to the child support enforcement system. "I am not paying child support for my boys, but I take care of them, though. ... That's why their mother never took me to court" Doc admitted. Child support meant a check to welfare; taking care of children entailed much more.

The lack of consistent contributions made fathers aware that their efforts did not measure up to success from their own expectations either. Tough prospects for family-wage jobs added to the tension that fathers felt between wanting to provide consistently and being unable to do so. Taking care of children consisted of providing financial help whenever the fathers could afford to do so. One father said,

I might give you \$200 at the end of the month, and I don't even care if the court knows or not. I give them what they need, what they want, their mamas always know, I don't give a damn how mad they are at me, they call me if they need something. If I can get it, I will. I'm going to make sure the courts see that I've got your 10 dollars [for child support], but this dress you've got on, I bought this too. If I can't do it, and their mamas can't do it, they've got grandmamas and granddaddies. It's going to come together. (Asante, 35)

Fathers identified three disincentives to paying into the state child support system. First, monthly payments went directly to the state to defray public aid benefits. Mothers and children in Illinois received only $\$ 50$ of that amount as pass-through money. Men regarded this payment 
as a responsibility to keep the state off their backs, not as a responsibility toward their children. Second, mothers and children could benefit more directly through a straight payment to the family. No money would be siphoned off to defray public aid, and no money would be reported for tracking purposes.

Third, there were few well-paying jobs with which to pay child support. General assistance to men in Illinois was cut completely in 1992. Job training was limited to state earnfare spots, which resulted in some decent part-time work, although some men shoveled snow and declared, "it was so bad that I will never work for anyone [other than myself] again." Marginalized from many jobs due to lack of education and hard skills, men could not count on consistent monthly paychecks.

\begin{abstract}
We made the best out of it [when she had the baby]. I started looking for more jobs. I tried to maintain. I could have just kept working at the car wash; I worked there for 4 years. I was 19 when I stopped, and then I worked for a temporary day labor agency. They liked me, but I never got the money I was supposed to be getting. And somewhere between all the red tape, they would not hire me permanently. (Miles, 30)
\end{abstract}

\title{
The Demands of Monthly Payments
}

After establishing paternity, most fathers who were unemployed were referred to earnfare positions and had $\$ 50$ transferred to their children from their checks. Subsequent payments ranged from $\$ 10$ to $\$ 50$ for each child if men remained in contingent and temporary employment. " $\$ 100$ for two boys $]$ is still a lot when you're not making any kind of money, [working part-time at a burger joint or Walmart]," Damian, 27, remarked. Some men wondered about their financial situations if they had not become fathers.

I love my daughters, but there is no telling what I'd be doing if they weren't here. That threw a monkey wrench into everything. I would be ahead of where I am now. Now, I have to go get some Pampers, and then I'm broke. It is so much stress to make sure she has food and everything. I can go a day, but she has to eat. And it's been this way for a long time. (Oscar, 25)

What loomed for many fathers was the question of what happened when they obtained good jobs and larger amounts of money would be transferred to the state. 'I'm in school, and they haven't gotten to me yet," Rashan, 21, admitted, "but from what I hear, if you're in school, 
they can't take more than $\$ 20$ per month from you. They may not mess with you, taking $\$ 100$ out of your check or more.” The threat of child support guided many fathers into school or unreported employment in an effort to maintain control over the small amounts of money that they did earn.

Fathers resisted child support policies not for the dollar amounts demanded but for not having the freedom to decide how to allocate resources as they chose. The child support system required frequent reports and updates on residency changes. Even when the system could work in their favor, many men refused to report the complex informal negotiations between parents.

My daughter's mother took her away from me to Mississippi for a year after I was paying child support. I could have had her thrown in jail, but that's not my m.o. I just waited it out and hoped it would pass. (Joe, 40)

Another father, whose ex-wife received public aid for his son, took the son into his household 6 years ago. The child support system did not have a record of this residence and custody change.

I don't feel I should be paying child support at all because he's staying with me. I haven't started paying yet. I don't think he even needs it. She gets the money for him, but he is staying with me. I just don't want [to get into discussion with those people]. (Rodney, 37)

\section{Difficulties in Reporting Employment}

More practically, the child support system required new hire employment reports from employers. Although the local economy of Chicago thrived in 1997 and 1998, most low-income African American men could expect only a succession of low-paying, temporary jobs. Most preferred not to discuss their sporadic job histories with government agencies. In particular, the majority of men in the study had criminal records that could threaten the substantial jobs which they could obtain. Policy options in welfare reform did little to address this difficult issue, and men remained caught, rotating between poor jobs and waiting to hear that their employers had to let them go.

There were few choices for fathers marginalized from the formal labor market. The informal economy offered flexibility, quick cash, and safety from precise reporting to state agencies. In addition, it did not require "proof" of activity for the child support system. Ruben, who 
repaired sports cars, had always received cash for his work. After a series of well-paying jobs, he took a "real" job for which he paid taxes and received a paycheck. "Suddenly, hello, here's child support. They established a high monthly payment, then I lost my job because my employer found out about my record. Now I have to try to change the support order" (Ruben, 32).

Child support courts assumed that Doc, who was surprised by the paternity system concerning his 8-year-old daughter, was irresponsible and unemployed. He was forced to take an earnfare slot that actually damaged his earning capacity.

I have to figure out where my next dollar is coming from. I don't want to do anything illegal. The judge said I was supposed to get a job. [But I have a job, detailing cars in the neighborhood], and looking for a real job with a paycheck takes away from my time to make any money at home.

(Doc, 35)

Other fathers opted for illegal alternatives due to the threat of being reported to child support. Kelvin "quit the best job I ever had trying to run away from child support. . . . I thought she could take all of my money." He wanted to live "below the radar" and began to deal drugs to make money off the books.

The youngest father in the sample provided his perspective on financial obligation:

The main thing that people talk about is financially taking care of their child, providing food, clothing, shelter. And the second thing is just spending time with them, taking time out for them. I was thinking that the ellipsis the system takes away from the second thing, and they really just emphasize the first part. And that really hurts the children. (Andre, 18)

If single fathers did not earn living wages, and therefore paid very low amounts of child support, perhaps their most important contribution to their children came in the time they offered as caregivers or as parental options for custody.

\section{CAREGIVING AND ACCESS TO CHILDREN}

\section{In-Kind Caregiving Supports}

Fathers valued their opportunities to take care of their children through visits, emotional support, teaching, and caregiving. Policy makers did 
not recognize these in-kind aspects of paternal involvement, although mothers and family members valued them. The difficult negotiations between coparents appeared to exist outside the visibility of state agencies. Many men cited their efforts to be caregivers as their most dramatic example of fathering.

I tell her now, it's not about me and her. It's about the kids. I'm not coming in her face telling her, look baby, you can trust me, I'm off drugs. I show it by faithfully coming around and having something, not just taking all the time. If we don't buckle up and listen now, we're going to lose these kids to the streets or [the Department of Family Services]. (Rich, 35)

A few coparents understood that their frustrations-not getting consistent support for the mothers or being denied time with the children for the fathers-stemmed from the same sources. Class and race inequalities were shared by men and women, because "times are tough for everybody, women too," as one father noted.

Under informal family agreements, five fathers were sole custodians of their children. Single fathers offered an option to mothers in treatment or in prison. Jelani was in the "reverse scenario" of most men:

My son's mother, I don't know where she is. ... I think she's in [a state prison]. I had been taking him on the weekends and summers, and she called me up and asked me to take him for 3 years. I haven't heard from her since. I just know she's having some kind of problems. (Jelani, 23)

Gary, a first-time father at 35, kept his daughter as a preferred placement to state foster homes when her mother was in a treatment program.

A number of other fathers worked off and on in the family households as caregivers for their children, while their unmarried partners received public aid.

I started watching my kids while my girl Steph worked at Wendy's. Usually the woman stayed home, but I reversed it. ... That was my philosophy. I enjoyed it. I changed diapers and all that. I cooked what I knew how to cook. Then she cooked the big meal when she got home from work. (Cory, 27)

In this situation, "invisible" fathers shared parenting roles and actively worked to counter barriers within policy systems which affected family life. For example, Damian, 27, tried to stay involved with his young family while motivating his partner to make lifestyle changes. 
They passed the law now so she only has 5 years on public aid. She talks like "they won't make us homeless and hungry." I tell her that they're looking at economics, not humanitarian issues. They may throw a few people a bone, but that's it. I see the handwriting on the wall. There are going to be a lot of women out here doing things that they shouldn't be doing, whoring, whatever, because there won't be enough jobs and they still have to take care of their kids. It's hard. . . . I'm trying not to leave.

(Damian, 27)

\section{Visitation and Tension Over Legal Decisions}

Fathers routinely opted for informal solutions to caregiving and access, avoiding the high emotional and financial costs of court dates and legal decisions. When they worked at being rightful fathers from policy makers' perspectives by paying child support and establishing paternity, the men expected to receive rights to see their children. There were no provisions in welfare reform policy to address caregiving rights. Some fathers could not gain the right to visitation because they did not have steady employment. Others lost the informal access that had been granted by mothers when they questioned legal arrangements.

I wanted to take my son with me to my house, for a visit without her around, because otherwise there's always an argument. I try to speak my piece, and the judge cut me short. They cut my time with her, Tuesdays and Thursdays from 5 to 9 . I got upset. I raised my little brother and sister, there's a 10-year break between us, my mom worked and I used to have to feed them and change their diapers. And they say [the mother] has to train me on how to raise a child. (Tyrell, 20)

After we proved the child was mine, we went for visitation. This was after years of being involved with my daughter. I was tired of going down to court, missing days of work. And I got a brick thrown in my face. I didn't get to see my child without supervised visitation. And I blew up. Why? What the hell are you talking about? Didn't need that before, why do I need that now? The mother and I became enemies again. (Gil, 27)

It was only through a rare perseverance and resourcefulness that fathers eventually saw change. Gil spent 3 years fighting with his exgirlfriend Sarah over visitation with his daughter. Sarah fought court appearances, failed to show for scheduled visitations, and shut down communication. Finally, Gil decided to slow down: "I thought that this isn't the way to do it, this fighting. I would let her see that I was serious, but that I didn't want to be her enemy. She needed time to work her 
situation out." After a year, informal negotiations worked: Sarah allowed their daughter to spend a weekend each month with Gil.

Fathers used the court system as a last resort, especially after witnessing state's obligations end with establishing men as fathers only through provision. It was difficult to even locate legal assistance for noncustodial fathers. Isaiah, after court cases involving his two daughters, decided that "you can present yourself the same way as an attorney, but you won't have a snowball's chance in hell, going in there as a poor Black father up against the state attorneys who represent the mother or [family services]" (Isaiah, 40).

\section{Custody Issues and Family Services}

State family services and foster care systems also played a prominent role in caregiving opportunities for fathers. Although the prospect of losing children "to the system" always was present, low-income single fathers had to cooperate with the foster care agency, which typically did not complete a diligent search for these men when custodial decisions arose. Theo, 26, lost his daughter to the foster care agency at the hospital, due to, from his perspective, "my tattoo, earrings, how I offended [the caseworker] after she cursed me out for sitting on the mother's hospital bed." He learned to deal exclusively with the agency, not the mother, even though the caseworkers "make me feel like dirt" by requiring him to attend programs to get supervised visitation. Alfred, 36, spoke consistently with family services caseworkers, who still would not consider him for custody after the mother took his child and ran from foster care to Texas. Only one father pursued the route of sole legal custody. After a long court battle with the state family services system, he was awarded custody.

Before this, I never knew that it was even legal for a father to have custody of his child. All I thought the men did was go by there on weekends and pay child support. I thought the mother would have to die for the man to have custody. (Isaiah, 40)

Custody was linked to the receipt of public aid. This led many lowincome families to accept the state's definition of children as their own kind of "dollar bills." Family members turned on each other in an effort to gain access to vital funds from public aid. Isaiah needed to contest in court the efforts of his daughter's aunt, who was only interested "in the 
aid check." Muhammed, 34, received restraining orders from his sister after he returned home from prison, "and it took me 90 days to get a court date to ask about my children. ... She wanted to keep that public assistance." Welfare reform policies, in this way, become deeply embedded in how families view custody.

\section{Monitoring Parenting Practices}

Verification of proper parenting, a third type of proof, was required in family services systems. Thorough monitoring of parenting practices was commonplace for low-income fathers and mothers receiving public aid. Reports to family services caseworkers threatened the rightful claim of any father and could even arise from within one's own family. Caseworkers had "heard from somewhere" that Gary's daughter was not related to him; later, he found that his own mother had called in a report. Before he could gain unsupervised visitation, Gary, 35, was called downtown repeatedly for surprise drug tests.

I kept coming up clean. So they gave it to me again. I had to do that about four times. One time they did it to me after court. It was a surprise right there. They would call me and say they wanted to talk to me and then test me. (Gary, 35)

Other fathers were given psychological exams, in which they could be deemed unfit for parenting due to past gang affiliations or time spent in prison, which would indicate violent tendencies. Fathers who could not attest to adequate communication skills were mandated to attend classes. Caseworkers used their own discretion to doubtfully question household maintenance (such as cleaning, grocery shopping, meal preparation) and child care (including, for men with daughters, ability to comb and style hair and to cope with menstruation).

Although family services caseworkers may have had reason to suspect inappropriate placement of children, the stereotypes of violent or irresponsible poor African American fathers were built into policies governing visitation and custody. Ruben, 32, received such physical abuse as a child that he made conscious efforts to defuse abusive situations with his children. When family services found his son bruised, they accused him of abuse. "And it messed [the caseworkers'] heads up, they felt it just had to be the daddy abusing these kids. And the kids kept telling them, their daddy don't do it. Their daddy fights people who do it" (Ruben, 32). 
Low-income single fathers who get lost in the family services system were perhaps most susceptible to the behavioral requirements of welfare reform's "new paternalism." From their perspective, their children needed support, and yet the focus fell on their inability to provide, which required prescriptive and at times punitive policy measures. Unfortunately, policies allocated little time or resources for changing life circumstances.

All this society knows about is corrections. Corrections don't happen, it's more like "Put them in a cell and treat them like cattle." They don't give a damn about counseling or rehabilitation. (Ruben, 32)

I didn't know that there were so many people going through what I was going through [in my family and in the courts].... People are calling us deadbeat dads. I've never seen a deadbeat volunteer for anything. Nobody is twisting our arms to be [good fathers]. (Isaiah, 40)

\section{SUMMARY AND DISCUSSION}

Focusing constructs of paternal involvement on caregiving capacity (in discussions of nurturant fathers) or on providing ability (in discussions of low-income single fathers) limits a more comprehensive understanding of fatherhood across race and class. I combine three aspects of involvement-rightful claims to fatherhood, financial support, and caregiving and access to children - to find the distinctions made by social policy about single fathers in low-income African American communities. For these fathers, "taking care" of their children often runs contrary to the new requirements of welfare reform policies.

Their experiences challenge researchers of the family to consider different family formations. Can the same processes and theories used in discussion of married families be used for nonresidential families of single parents? Assumptions about fatherhood based on the necessity of marriage and employment continue to affect discussions of family formation. For example, it is assumed that unmarried fathers are absent fathers. However, men in this study may give care more frequently than fathers who are married and have family-supporting jobs. Their efforts, however, are ignored and undervalued by policy makers and communities alike (van Dongen, 1995).

A father's place in the family life course has been limited due to normative expectations of the father as provider, not as caregiver or kin keeper. For the men in this study, caregiving was vital to parenting, a 
belief that was heightened when it was difficult to find a good job. These men may not be described as "renegade relatives" who could "not be counted on to carry out kin tasks" (Stack \& Burton, 1993). Some fathers even provided a paternal kin network of resources to their children, as well as father-centered families in which children of different mothers came to know each other through their relationships with their fathers.

The role of mothers in the family may be shifting as well. This study shows a need for single fathers to support single mothers who have problems with substance abuse and incarceration, or who may be subject to new work requirements under welfare reform. The frustration of efforts by low-income single fathers indicates how social policies can disrupt kin work and kin time patterns. These policies served to create new sets of family expectations for parents, particularly with current paternity and child support legislation.

Unfortunately, it is still difficult to gain access to the experiences of low-income single fathers. The time investment required to gain rapport and trust with the fathers in this study suggests limitations to replication. This study is limited to one community of urban African American fathers. The balance of caregiving and providing may be quite different for low-income single fathers who are Latino, Asian American, or European American. Also, men in the study were embedded in a preexisting discourse and had found voices as fathers through a parenting program that advocated for them (Lupton \& Barclay, 1997). This discourse may have heightened their interest in appearing to be "good fathers" in the face of punitive social policies. That said, their experiences as related in this study do provide insight into ways in which policy systems can import adversarial relations into family settings.

\section{IMPLICATIONS FOR SOCIAL POLICY}

Without recognizing the impact of social policy, it is difficult to interpret the lives and actions of fathers. This study provides evidence that, contrary to many social stereotypes, low-income single fathers are involved in the lives of their children. The question "where are the men?" reflects the social and economic isolation of these fathers, but it does not necessarily reflect a lack of effort. Policy makers constrain role options for noncustodial fathers by requiring only their limited finances.

Men may resist paternity establishment, child support, and foster care due to negative experiences with policy institutions such as schools, prisons, and the military. Prior experiences in these institutions, 
particularly for high rates of African American men with felony charges, bar further participation in policy systems: Fathers cannot receive public aid and may be denied visitation or custody. Welfare reform systems demand more intensive verification and monitoring of low-income and minority families' parenting practices, employment statuses, and biological links to children than for any other group of families in society. In effect, long before fatherhood begins, some men appear to be confined to the margins of their families by the discretion of policy makers.

Implications from this study are twofold. First, by examining the relationship between caregiving and providing, family-supportive social policies can resolve the tensions between community strategies for involvement and legal strategies that may deter any involvement at all. Single fathers often desire to live up to the culture of new fatherhood but fall short when their worth is measured simply in dollar bills. This is particularly true when assumptions about their inconsistency, unwillingness to parent, or past records of "street days" give them an " $\mathrm{X}$ " on their backs that can never be removed. Even after proving their worthiness as fathers, some men need to repeatedly demonstrate their involvement and will.

Second, supportive family policies should address fathers in reality, in all of their diversity, not just in theory. Assumptions about marriage and access to employment divide good fathers from bad fathers. Policy makers cannot equate marriage with parenting, because the experiences of these low-income single fathers reflect paternal involvement. Which part of the term single parents is most problematic: the fact that a woman or man raises a child outside of marriage, or the fact that there are fewer parents as resources for children (McLanahan \& Sandefur, 1994)? Family policies can guarantee parental rights and responsibilities whether marriage exists or not. Family policies can de-escalate conflict within the family by taking the focus off of finances and building concern for the emotional as well as financial well-being of children. At task is not how to best define fathering but how to best equip men to be involved with their children.

\section{REFERENCES}

Allen, W., \& Connor, M. (1997). An African American perspective on generative fathering. In A. Hawkins \& D. Dollahite (Eds.), Generative fathering: Beyond deficit perspectives (pp. 52-70). New York: Sage. 
Allen, W., \& Doherty, W. (1996). The responsibilities of fatherhood as perceived by African American teenage fathers. Family in Society: Journal of Contemporary Human Services, 79, 142-155.

Anderson, E. (1990). Streetwise: Race, class, and change in an urban community. Chicago: University of Chicago Press.

Bernard, J. (1981). The good provider role: Its rise and fall. American Psychologist, 36, 1-12.

Boggess, J., \& Roulet, M. (1998). Parenting, conflict, and welfare reform. Chicago: Center for Fathers, Families, and Public Policy.

Bowman, P. (1988). Postindustrial displacement and family role strains: Challenges to the Black family. In P. Voydanoff \& L. Majka (Eds.), Familes and economic stress (pp. 75-96). Beverly Hills, CA: Sage.

Brewer, R. (1994). Race, class, gender, and U.S. state welfare policy: The nexus of inequality for African American families. In G. Young \& B. Dickerson (Eds.), Color, class, and country: Experiences of gender. Atlantic Highlands, NJ: Zed Books Ltd.

Bronfenbrenner, U. (1979). The ecology of human development: Experiments by nature and design. Cambridge, MA: Harvard University Press.

Cohen, D. (1998). The changing roles of low-income fathers: Using a public health model to guide social policy. News and Issues, 8, 68 .

Coltrane, S. (1996). Family man: Fatherhood, housework, and gender equity. New York: Oxford University Press.

Daly, K. (1995). Reshaping fatherhood: Finding the models. In W. Marsiglio (Ed.), Fatherhood: Contemporary theory, research, and social policy (pp. 21-40). Thousand Oaks, CA: Sage.

Doherty, W. (1997). The best of times and the worst of times: Fathering as a contested arena of academic discourse. In A. Hawkins \& D. Dollahite (Eds.), Generative fathering: Beyond deficit perspectives (pp. 217-227). Thousand Oaks, CA: Sage.

Dollahite, D., Hawkins A., \& Brotherson, S. (1997). Fatherwork: A conceptual ethic of fathering as generative work. In A. Hawkins \& D. Dollahite (Eds.), Generative fathering: Beyond deficit perspectives (pp. 17-35). Thousand Oaks, CA: Sage.

Duster, T. (1995). Postindustrialization and youth unemployment: African Americans as harbingers. In K. McFate, L. Lawson, \& W. J. Wilson (Eds.), Poverty, inequality, and the future of social policy (pp. 461-486). New York: Russell Sage.

Edin, K., \& Lein, L. (1997). Making ends meet: How single mothers survive welfare and low-wage work. New York: Russell Sage.

Epstein, W. (1997). Welfare in America: How social science fails the poor. Madison: University of Wisconsin Press.

Freedman, D., Thornton, A., Camburn, D., Alwin, D., \& Young-Demarco, L. (1988). The life history calendar: A technique for collecting retrospective data. Sociological Methodology, 18, 37-68.

Furstenberg, F. (1988). Good dads-bad dads: Two faces of fatherhood. In A. Cherlin (Ed.), The changing American family and public policy (pp. 193-218). Washington, DC: Urban Institute Press.

Furstenberg, F. (1992). Daddies and fathers: Men who do for the families and men who don't. In F. Furstenberg, K. Sherwood, \& M. Sullivan (Eds.), Caring and paying: What mothers and fathers say about child support. New York: MDRC.

Furstenberg, F. (1995). Fathering in the inner city: Paternal participation and public policy. In W. Marsiglio (Ed.), Fatherhood: Contemporary theory, research, and social policy (pp. 119-147). Thousand Oaks, CA: Sage. 
Garbarino, J., Dubrow, N., Kostelny, K., \& Pardo, C. (1992). Children in danger: Coping with the consequences of community violence. San Francisco: Jossey-Bass.

Garfinkel, I., McLanahan, S., \& Robins, P. (1992). Child support assurance. Washington, DC: The Urban Institute Press.

Gerson, K. (1993). No man's land: Men's changing commitments to family and work. New York: Basic Books.

Glaser, B., \& Strauss, A. (1967). The discovery of grounded theory: Strategies for qualitative research. New York: Aldine.

Griswold, R. (1993). Fatherhood in America: A history. New York: Basic Books.

Jarrett, R. (1994). Living poor: Family life among single parent, African American women. Social Problems, 41, 30-49.

Johnson, E., \& Doolittle, F. (1996). Low income parents and the Parents' Fair Share Demonstration: An early demographic look at low income non-custodial parents and how one policy initiative has attempted to improve their ability to pay child support. New York: MDRC.

Johnson, W. (in press). Work preparation and labor market experiences among urban, poor, nonresident fathers. In S. Danziger \& A. Lin (Eds.), The social contexts of work and family life: Qualitative research on the African American experience. Ann Arbor: University of Michigan Press.

Lamb, M., Pleck, J., Charnov, E., \& Levine, J. (1987). A biosocial perspective on paternal behavior and involvement. In J. Lancaster, J. Altmann, A. Rossi, \& L. Sherrod (Eds.), Parenting across the lifespan: Biosocial dimensions (pp. 111-142). New York: Aldine.

LaRossa, R. (1997). Modernization of fatherhood: A social and political history. Chicago: University of Chicago Press.

Lerman, R. (1993). A national profile of young unwed fathers. In R. Lerman \& T. Ooms (Eds.), Young unwed fathers: Changing roles and emerging policies (pp. 27-51). Philadelphia, PA: Temple University Press.

Liebow, E. (1967). Tally's corner: A study of Negro street corner men. Boston: Little, Brown.

Lupton, D., \& Barclay, L. (1997). Constructing fatherhood: Discourses and experiences. Thousand Oaks, CA: Sage.

Marsiglio, W. (1995). Fathers' diverse life course patterns and roles: Theory and social interventions. In W. Marsiglio (Ed.), Fatherhood: Contemporary theory, research, and social policy (pp. 78-101). Thousand Oaks, CA: Sage.

McLanahan, S., \& Sandefur, G. (1994). Growing up with a single parent: What hurts, what helps. Cambridge, MA: Harvard University Press.

McLoyd, V. (1989). Socialization and development in a changing economy: The effect of paternal job and income loss on children. American Psychologist, 44, 293-302.

Mead, L. (1997). The rise of paternalism. In L. Mead (Ed.), The new paternalism: Supervisory approaches to poverty. (pp. 1-36). Washington, DC: Brookings Institute.

Mincy, R., \& Pouncy, H. (1997). Paternalism, child support enforcement, and fragile families. In L. Mead (Ed.), The new paternalism: Supervisory approaches to poverty (pp. 130-160). Washington, DC: Brookings Institute.

Mincy, R., \& Sorensen, E. (1998). Deadbeats and turnips in child support reform. Journal of Policy Analysis and Management, 17, 44-51. 
Palkovitz, R. (1997). Reconstructing "involvement": Expanding conceptualizations of men's caring in contemporary families. In A. Hawkins \& D. Dollahite (Eds.), Generative fathering: Beyond deficit perspectives (pp. 200-216). Thousand Oaks, CA: Sage.

Rainwater, L. (1970). Beyond ghetto walls: Black family life in a federal slum. New York: Aldine.

Ray, A., \& Hans, S. (1997, November). Contributions to African American mothers'views of their children's fathers' caregiving: Fathers past and present. Paper presented at National Council on Family Relations Annual Meeting, Arlington, VA.

Roschelle, A. (1997). No more kin: Exploring race, class, and gender in family networks. Thousand Oaks, CA: Sage.

Stack, C. (1974). All our kin: Strategies for survival in a Black community. New York: Harper.

Stack, C., \& Burton, L. (1993). Kinscripts. Journal of Comparative Family Studies, 24, 157-170.

Stier, H., \& Tienda, M. (1993). Are men marginal to the family? Insights from Chicago's inner city. In J. Hood (Ed.), Men, work, and family (pp. 23-44) . Thousand Oaks, CA: Sage.

Sullivan, M. (1989). Absent fathers in the inner city. Annals of the American Academy of Political and Social Science, 501, 48-58.

Sullivan, M. (1993). Young fathers and parenting in two inner-city neighborhoods. In R. Lerman \& T. Ooms (Eds.), Young unwed fathers: Changing roles and emerging policies (pp. 52-73). Philadelphia, PA: Temple University Press.

Taylor, R., Leashore, B., \& Toliver, S. (1988). An assessment of the provider role as perceived by Black males. Family Relations, 37, 426-431.

van Dongen, M. (1995). Men's aspirations concerning child care: The extent to which they are realized. In M. van Dongen, G. Frinking, \& M. Jacobs (Eds.), Changing fatherhood: An interdisciplinary perspective (pp. 91-105). Amsterdam: Thesis Publishers.

Wacquant, L. (1996). The rise of advanced marginality: Notes on its nature and implications. Acta Sociologica, 39, 121-139.

Waller, M. (1996). Redefining fatherhood: Paternal involvement, masculinity, and responsibility in the "other America." Unpublished doctoral dissertation, Princeton University.

Waller, M. (1997, August). Paternity establishment, child support, and paternal responsibility: Reconciling formal and informal systems of support in low-income communities. Paper presented at American Sociological Association Annual Meeting, Toronto, Ontario, Canada.

Wilson, W. J. (1996). When work disappears: The world of the new urban poor. New York: Knopf. 